\title{
Factors of Stock Return and Carhart Model: The Case of Dhaka Stock Exchange (DSE) of Bangladesh
}

\author{
Mohammad Akter Hossan ${ }^{1} \&$ Mohammad Joynal Abedin ${ }^{1}$ \\ ${ }^{1}$ Department of Finance, University of Chittagong, Chittagong, Bangladesh \\ Correspondence: Mohammad Akter Hossan, Department of Finance, University of Chittagong, Bangladesh. Tel: \\ 88-017-127-7677. E-mail: mahossan@yahoo.com
}

Received: February 19, 2019

Accepted: March 3, 2019

Online Published: April 25, 2019

doi:10.5539/ijef.v11n6p14

URL: https://doi.org/10.5539/ijef.v11n6p14

\begin{abstract}
The objective of this study is to find factors of stock return by testing validity of Carhart model in Dhaka Stock Exchange (DSE) of Bangladesh. For this purpose, this study uses monthly excess return of portfolios, size, book-to-market value, market return, and price momentum data of 109 sample firms to calculate return factors such as market risk premium, size premium (SMB), value premium (HML), and momentum effect (UMD) for the sample period of 2005 to 2014. Then a total of ten portfolios, six based on size and book-to-market value and four based on size and price momentum, are constructed in this study. Excess return of each of these portfolios are calculated and regressed on the above four factors. Results of this study reveal that in DSE, market risk premium is positively and significantly related with the excess return of all portfolios; Size premium is found positively and significantly related with the return of small size portfolios; Value premium is found negatively and significantly related with the returns of all portfolios except one big portfolio $(\mathrm{B} / \mathrm{H})$; momentum effect is found positively and significantly related to the excess return of up (U), big (B), and small (S) size portfolios. It is also evident from $R^{2}$ value, $F$ statistic, and robustness test of this study that four-factor model is valid and it can predict portfolio returns accurately when there is no abnormality such as market crash occurs in DSE.
\end{abstract}

Keywords: excess -return, market risk, size, book-to-market, momentum

\section{Introduction}

According to ex-ante version of asset pricing models of Sharpe (1964), Lintner (1965); Mossin (1966), and Jensen (1968), price of a stock in any stock market is equal to its expected return. Expected return of their models is assumed to be determined only by market-specific factor such as market return or market risk premium. In contrast, Basu (1977), Banz (1981) Rosenberg, Reid, and Lanstein (1985) postulate that firm-specific factors such as price-to-earnings ratio, firm size, firm value might determine expected return of a stock. In addition, Jegadeesh and Titman (1993) find that behavioral factor like momentum might also determine return of stocks; and Hossan and Park (2010) report that overreaction to firm-specific information is the source of momentum profit in Dhaka Stock Exchange (hereafter DSE) of Bangladesh. Therefore, asset pricing literatures have observed a long debate on whether market-specific or firm-and behavioral-specific or all of them determine expected return of a stock. In an attempt to resolve this debate Fama and French (1996) reinvestigate the issue by considering above mentioned market-and firm-specific factors in a multi-factor model, and find that three factors such as market return; size, and book-to-market value determine expected return of stock. This three-factor model of Fama and French (1996), later on, is being criticized since it denies momentum as a factor of expected returns of stock. Therefore, Carhart (1997) extends three-factor model of Fama and French (1996) by taking momentum of Jegadeesh and Titman (1993) into account and find that short-term momentum explains return of a stock. In addition, Carhart (1997) model explains returns of stock better than three-factor model of Fama and French (1996) in the stock markets of both developed and emerging countries (Lozano, 2006; Ammann \& Steiner, 2008; Gregory, Tharyan, \& Chiristidis, 2013; Bretschger \& Lechthaler, 2012; Artmann, Finter, \& Kempf, 2012; Tjandrasa, 2015; Czapkiewicz \& Wójtowicz, 2014). Therefore, this study applies Carhart (1997) model to find factors of stock returns in Dhaka Stock Exchange (hereafter DSE) of Bangladesh.

However, identifying factors of returns of stock in emerging stock market of Bangladesh is worthy at least for three reasons. First, momentum strategy based on previous thirty six months' returns and holding it for next thirty six months is found profitable in Dhaka Stock Exchange (Hossan \& Park 2010). Second contradictory 
research findings regarding factors of returns of stock are observed in the stock market of Bangladesh. As for example, the negative relationship between market return and returns of stock of Mobarek and Mollah (2005) contradicts with positive relationship of the same of Rahman, Baten, and Alam (2006) and Hasan, Alam, Amin, and Rahaman (2015) in DSE, which is one of the emerging stock markets in the world. In addition, it challenges the argument of having positive relationship between market return and returns of stock of ex-ante asset pricing models and motivates the researchers to initiate this study. Third, Hasan et al. (2015) claim that there remains no other factors to explain returns of stock in DSE after applying three-factor model of Fama and French (1996). This claim of Hasan et al. (2015) suffers from the drawback that their study violates the condition of eligible samples for testing three-factor model of Fama and French (1996) by including bank and non-bank financial institutions into their samples. Therefore, this study sets finding factors of returns of stock by testing Carhart (1997) model in DSE as its main objective, which has been pursued through a portfolio based analysis using a data set of 109 firms for the period of 2005 to 2014.

The rest of this study thus organized as follows: section two reviews relevant literatures for this study. Section three discusses about sample firms and periods, data, and methodology. Section four reports the findings of this study and section five draws conclusion on this study.

\section{Literature Review}

Asset pricing literatures experience a long debate on factors of returns of stock. As for example, Sharpe (1964) first identifies market return as the only factor of expected return of a stock. He argues that return of an individual stock is positively and linearly related with the market return. In his model Sharpe (1964) measures magnitude of dependency of stock returns on market by the parameter beta $(\beta)$. Later the capacity of beta to explain returns of stock is questioned in the study of Novak and Petr (2011), Mobarek and Mollah (2005), and Chowdhury and Sharmin (2013) respectively in Swedish and Dhaka stock market. These studies reveal that beta has either little information about stock returns or it is totally unrelated to the cross section returns of stock. Therefore, it becomes interesting to find which factors explain returns of stock in emerging stock market. In addition, it has been found in US stock markets that P/E ratio (Basu, 1977), size (Banz, 1981), and value (Stattman, 1980; Porta, Lakonishok, Shleifer, \& Vishny, 1997; and Griffin \& Lemmon, 2002) individually capable to explain returns of stock. But Fama and French (1993) when consider beta, size, book-to-market value ratio, price-to-earnings ratio and leverage in a multi-factor model to explain cross-section returns of stock they find that a combination of size and book-to-market value ratio absorbs the explanatory power of the other factors. As a result, Fama and French (1996) take beta, SMB (small minus big), and HML (high minus low) into account to develop another multifactor asset pricing model named three-factor model to explain returns of stock.

In addition, Jegadeesh and Titman (1993) introduce another factor of stock returns named momentum. They suggest that buying stocks performed well in the past and selling stocks performed poor in the past will generate significant positive returns over 3 to 12 month holding period. In 1997 Carhart reexamines momentum strategy of Jegadeesh and Titman (1993) on mutual fund performance over a period of 1962-1993 and demonstrates that size and momentum strategy explain $4.6 \%$ out of $8 \%$ excess return of individual stocks. Carhart (1997) also find that short-term momentum strategy suggested by Jegadeesh and Titman (1993) is more accurate than long-term i.e. 2 to 5 years momentum strategy. Therefore, short-term momentum is also considered another factor of returns of stock in Carhart (1997) model. In a reply to Carhart (1997), Fama and French (2012) examine momentum adjusted four-factor model in 23 developed countries dividing into four regions such as (1) North America, (2) Europe, (3) Japan, and (4) Asia Pacific over a period of 1989-2011. Their study aims at explaining mean return by using size, value and momentum strategy in developed countries and reveals that value and momentum premium is everywhere except Japan. Bretschger and Lechthaler (2012) also examine the power of four-factor model in Japanese stock market over a period of 1984-2009 and find that Carhart (1997) model performs reasonably well in explaining stock returns. Nwani (2015) also examines multifactor asset pricing model in London stock exchange over a period of 1996-2003 and find significant explanatory power of both three-and four-factor model except size effect. In addition, Artmann et al. (2012) find Carhart's four-factor model performs better than three-factor model of Fama and French (1996) in German stock exchange over a period of 1963-2006. In addition, Lozano (2006) in USA, Ammann and Steiner (2008) in Switzerland, Tjandrasa (2015) in Indonesia, Czapkiewicz and Wójtowicz (2014) in Poland find four-factor model as robust. Lozano (2006) find that pricing errors are jointly significant in three-factor model but not in four-factor model. So, it is evident from the discussion above that four-factor model is superior to three-factor model to explain of returns of stock.

In DSE, an emerging stock market, research findings on explanatory power of factors of stock returns are found mixed in nature. As for example, Mobarek and Mollah (2005), Chowdhury and Sharmin (2013) find negative 
relationship between stock returns and market beta. Regarding other factors of stock returns, Mobarek and Mollah (2005) find that size, B/M ratio, volume, earnings yield, and cash flow yield have significant influence on stock returns in DSE, which contradict with the findings of Chowdhury and Sharmin (2013). Because Chowdhury and Sharmin (2013) find that size, dividend yield, P/E ratio, and liquidity have no ability to explain the cross-section returns of stock. On the contrary, Rahman et al. (2006) and Hasan et al. (2015) find stock returns are positively and linearly related with market return. Both of these studies signify explanatory power of common risk factors such as size and $\mathrm{B} / \mathrm{M}$ ratio in the cross-section returns of stock. But momentum still remains unexamined factor of returns of stock in DSE. Therefore, this study aims at testing the validity of Carhart (1997) model in DSE.

\section{Methodology}

\subsection{Sample and Data}

This study uses monthly stock price data of all listed firms of DSE for the period of January 2005 to December 2014. There are 333 firms listed in DSE during this sample period. From these listed firms this study selects samples following three criteria. First, firms listed before 1 January, 2005 are considered in this study for making it sure that at least 60 months return data will have to estimate beta, to have a unified sample period for all stocks, and to have a sufficient number of stocks to form well diversified portfolios. Second, this study excludes some inactive stocks based on their trading activity (suspension of trade for a longer period) and availability of data. Thirdly, bank and non-bank financial institutions are excluded from the sample of this study because their asset-liability structure with high financial leverage hinders the comparability of book-to-market ratio with other non-financial institutions (Fama \& French, 1996). Finally, it is found that 109 firms satisfy these three criteria; and these firms are considered as sample firms for this study. In addition, this study considers 91-day Treasury bill rate (converted into monthly rate) as a proxy of risk-free rate because the government of Bangladesh has suspended the auction of 28-day Treasury bill in 2008-2009. Data of monthly stock price, book value per share, and number of share outstanding used in this are collected from DSE. For market return data this study collects DSE general (DGEN) and DSEX index from DSE. In 2013, DGEN index is being declared obsolete and DSEX index has been introduced. For avoiding complexities, this study uses average of DGEN and DSEX for computing market return of the year 2013.

\subsection{Construction of Portfolios}

Following the method of Fama and French (1992, 1993, 1996, and 2010) and Carhart (1997), all sample stocks are sorted in an ascending order based on their market capitalization at the end of each year. Then percentile is used to divide stocks into small(S) and big (B) portfolios. Small portfolio consists of stocks of lower $50^{\text {th }}$ percentile and big (B) portfolio consists of stocks of upper $50^{\text {th }}$ percentile.Again, all selected sample stocks are independently sorted based on their book-to-market equity. The sorted samples are divided into three portfolios such as high $(\mathrm{H})$, medium $(\mathrm{M})$, and low $(\mathrm{L})$ using percentiles. As for example, high $(\mathrm{H})$ portfolio includes top 30 percent firms, medium (M) portfolio includes middle 40 percent firms, and low (L) portfolio includes lower 30 percent firms. Then six portfolios such as small-high $(\mathrm{S} / \mathrm{H})$, small-medium $(\mathrm{S} / \mathrm{M})$, small-low (S/L); big-high $(\mathrm{B} / \mathrm{H})$, big-medium $(\mathrm{B} / \mathrm{M})$, and big-low $(\mathrm{B} / \mathrm{L})$ are formed by the intersection of size and book-to-market value. Now, size premium (SMB) is calculated in equation (1) below by taking difference between mean monthly return of three small and big portfolios. It needs to be mentioned that equal weights are given to each small and big portfolios of equation (1) while averaging monthly return of small and big portfolios. Therefore,

$$
\mathrm{SMB}=\frac{1}{3}(S / H+S / M+S / L)-\frac{1}{3}(B / H+B / M+B / L)
$$

In order to calculate value premium, four portfolios such small-high $(\mathrm{S} / \mathrm{H})$, big-high $(\mathrm{B} / \mathrm{H})$; small-low (S/L big-low (B/L) from above are considered and used in equation (2) below.

$$
\mathrm{HML}=\frac{1}{2}(S / H+B / H)-\frac{1}{2}(S / L+B / L)
$$

For calculating the momentum factor, all samples are independently sorted based on their prior one year performance. This study doesn't consider any lag for calculating the yearly return. All sample firms are then grouped into three groups using percentile such as up(U) portfolio includes 30 percent of higher returns, neutral(N) portfolio includes middle 40 percent and down(D) portfolio includes 30 percent of lower returns. This study uses two extreme portfolios such as up(U) and down(D). Then intersecting with the size groups again there would be four portfolios such as small-up (S/U), small-down (S/D), big-up (B/U), and big-down (B/D) based on size and momentum. Next, momentum effect (i.e. UMD) in equation (3) is calculated by taking difference between the equally weighted mean monthly return of up and down portfolios. Therefore, 


$$
\mathrm{UMD}=\frac{1}{2}(S / U+B / U)-\frac{1}{2}(S / D+B / D)
$$

All portfolios are then reshuffled at the end of each year over the sample period.

\subsection{Model}

This study employs four-factor model of Carhart (1997) and estimates coefficients of this model by running 120 regressions with the monthly excess return of each portfolio and the monthly return of explanatory factors computed at the beginning of the corresponding month. This study uses t-statistics and $p$-value to assess the significance of the estimated coefficients and employ F-test to find the overall significance of the model.This study calculates month end returns using the formula in equation (4) below.

$$
R_{i, t}=\ln P_{i, t}-\ln P_{i, t-1}
$$

Where $R_{i, t}$ is the month end return of stock $i$ at month $t$, $\ln$ represents the natural $\log , P_{i, t}$ is the month end price of stock $i$ at month $t$ and $P_{i, t-1}$ is the month end price of stock $i$ at prior to month $t$. To isolate the factor premium over the monthly excess return of the portfolios this study applies the four factor model of Carhart. This model includes four explanatory factors to explain the monthly excess return of portfolios. The first factor is basic CAPM factor named market risk premium which is the difference between the return of aggregate market index and risk free rate of return. The second factor is size premium (SMB, small minus big) which is based on the market capitalization. The third factor is value premium (HML, high minus low) which is based on the book-to-market equity. The final one is called momentum premium (UMD, up minus down) which is based on the return of prior on year. Including these factors the model stands as:

$$
R_{p, t}=R_{f, t}+\beta_{p, t}^{m p}\left(R_{m, t}-R_{f, t}\right)+\beta_{p, t}^{s m b}(S M B)+\beta_{p, t}^{h m l}(H M L)+\beta_{p, t}^{u m d}(U M D)
$$

Where $R_{p, t}$ is the return on equal weighted portfolio $p$ at the month of $t, R_{f, t}$ is the risk-free rate of return at month $t, \beta_{p, t}^{m p}$ is the responsiveness or coefficient of market premium for portfolio $p$ at the month $t$, $\left(R_{m, t}-R_{f, t}\right)$ is the market risk premium; here $R_{m, t}$ is the market return for the month $t$ calculated by $R_{m, t}=\left[\frac{I_{t}-I_{t-1}}{I_{t-1}} \times 100\right]$ where, $I_{t}$ represents index value at the end of month $t, I_{t-1}$ is the month end index value prior to month $t, \beta_{p, t}^{s m p}$ is the coefficient of SMB (Small Minus Big) for the portfolio $p$ at the month $t$. SMB is the factor premium for size effect. $\beta_{p, t}^{h m l}$ is the coefficient of HML(High Minus Low) for the portfolio $p$ at the month $t$, HML is the factor premium for value effect, $\beta_{p, t}^{\text {umd }}$ is the coefficient of UMD (Up Minus Down) for the portfolio $p$ at the month $t$ and UMD is the factor premium for momentum effect. In order to test the above equation (5), it has been altered as follows.

$$
R_{p, t}-R_{f, t}=\alpha_{p, t}+\beta_{p, t}^{m p}\left(R_{m, t}-R_{f, t}\right)+\beta_{p, t}^{s m b}(S M B)+\beta_{p, t}^{h m l}(H M L)+\beta_{p, t}^{u m d}(U M D)+\varepsilon_{p, t}
$$

Where $R_{p, t}-R_{f, t}$ is the monthly excess return of portfolio $p$ at month $t$, and $\alpha_{p, t}$ is the estimated intercept of portfolio $p$ at month $t$. According to Fama and French (1996) the estimated intercept in regression equation will be closer to zero and $\varepsilon_{p, t}$ is the standard error for the portfolio $p$ at the month $t$.

Finally, this studyestimates expected return of each of the ten portfolios of sub-section 3.2 of this study for each sample year by applying the four-factor model in equation (6); and calculates annual expected return for each sample year by taking average of expected returns of these ten portfolios for that particular year. Similarly, annual actual return of each of the ten portfolios of sub-section 3.2 for each sample year is also calculated. Then, differences between annual expected and actual return are calculated for each sample year and tested if these differences are statistically significant. Finding insignificant differences between these two returns is considered as an evidence of robustness of the regression parameters of this study.

\section{Results}

\subsection{Descriptive Statistics}

Table 1 represents summary statistics of mean monthly returns of six portfolios based on size and book-to-market and among these portfolios of Table $1, \mathrm{~S} / \mathrm{H}$ (small in size and high in book-to-market ratio) produces the highest excess return of $0.65 \%$ per month where as the $\mathrm{B} / \mathrm{L}$ (big in size and low in book-to-market ratio) produces the lowest excess return of $-1.67 \%$ per month, indicate the presence of size (SMB, small minus big) and value premium (HML, high minus low) in DSE. In addition, Table 1 reveals strong size effect for small portfolios i.e. 
small firms outperform big firms in terms of mean monthly returns in DSE. Size effect in Table 1 produces higher return such as [-0.2316-(-1.6732)] 1.44\% per month in case of low portfolio in DSE. Table 1 also reveals that value premium in case of small portfolios is [0.6453-(-0.2316)] 0.88\% per month while the same for big portfolios is [0.3546-(-1.6732)] 2.03\% per month in DSE. This finding rejects the same of Fama and French (1993) that value premium is high in case of small portfolios. Therefore, emerging market like DSE value premium exits with big portfolio, which is opposite to case of developed countries.

Table 1.Summary statistics of return of portfolios constructed based on size and book-to- market

\begin{tabular}{lcccccc}
\hline & $\mathrm{B} / \mathrm{H}$ & $\mathrm{B} / \mathrm{M}$ & $\mathrm{B} / \mathrm{L}$ & $\mathrm{S} / \mathrm{H}$ & $\mathrm{S} / \mathrm{M}$ & $\mathrm{S} / \mathrm{L}$ \\
\hline Mean & 0.3546 & -0.5279 & -1.6732 & 0.6453 & 0.5078 & -0.2316 \\
Median & 1.0582 & 0.6673 & 0.2381 & 0.4999 & 1.0164 & 0.4179 \\
Standard Deviation & 12.4953 & 13.5276 & 22.6030 & 16.2952 & 17.6226 & 19.6228 \\
Minimum & -61.7533 & -83.9540 & -223.8430 & -132.2080 & -134.8970 & -167.2670 \\
Maximum & 31.7598 & 44.7739 & 38.0192 & 38.7546 & 51.3027 & 52.9220 \\
Kurtosis & 5.3199 & 14.8864 & 79.6861 & 37.0105 & 29.7425 & 44.6521 \\
Skewness & -1.1078 & -2.3718 & -8.1236 & -4.3676 & -3.6850 & -5.1021 \\
Count & 120 & 120 & 120 & 120 & 120 & 120 \\
\hline
\end{tabular}

Source: Authors.

Table 2 represents summary statistics of four portfolios constructed based on size and momentum. In Table 2, size effect produces higher return at a rate of [0.5044-(-1.0085)] $1.51 \%$ per month in case of up portfolio in DSE. Table 2 also shows that momentum strategy produces mean monthly return at a rate of [0.5044-(-0.0690)] 0.57\% per month for the small portfolios. But momentum strategy produces negative return at a rate of [-1.0085-(-0.2154)] $-0.7931 \%$ per month for big portfolios of Table 2 which is ambiguous in an emerging market like DSE.

Table 2. Summary statistics of return of portfolios constructed based on size and momentum

\begin{tabular}{lcccc}
\hline & $B / U$ & $B / D$ & $S / U$ & $S / D$ \\
\hline Mean & -1.0085 & -0.2154 & 0.5044 & -0.0690 \\
Median & -0.2549 & -0.3641 & 0.9646 & 0 \\
Standard Deviation & 18.4446 & 12.1045 & 20.3174 & 16.0367 \\
Minimum & -152.7310 & -73.3858 & -172.0120 & -118.2520 \\
Maximum & 49.6274 & 33.6511 & 55.2541 & 43.5715 \\
Kurtosis & 39.4323 & 11.9573 & 44.2096 & 25.0518 \\
Skewness & -4.9112 & -1.9878 & -5.13158 & -3.1043 \\
Count & 120 & 120 & 120 & 120 \\
\hline
\end{tabular}

Source: Authors.

Table 3 represents summary statistics of mean monthly return of explanatory variables i.e. $R_{f}, R_{m}-R_{f}$, SMB, HML, and UMD. Among these variables HML produces highest positive return (1.4523), which is a strong evidence of value effect in DSE. Table 3 shows that return from size (SMB) and market premium are $0.92 \%$ and $0.53 \%$, respectively. In addition, a mean negative return of $-0.11 \%$ from momentum factor is found in Table 3 .

Table 3. Summary statistics of explanatory variables over the sample period

\begin{tabular}{lccccc}
\hline & $R_{f}$ & $R_{m}-R_{f}$ & SMB & HML & UMD \\
\hline Mean & 0.5736 & 0.5295 & 0.9227 & 1.4523 & -0.1099 \\
Median & 0.6078 & 0.4055 & 0.6288 & 0.4629 & 0.7782 \\
Standard Deviation & 0.1938 & 8.3875 & 6.6201 & 11.1521 & 8.5884 \\
Minimum & 0.1700 & -30.9168 & -21.6070 & -16.2142 & -66.5524 \\
Maximum & 0.9478 & 30.0285 & 28.0716 & 98.5741 & 16.4130 \\
Kurtosis & 0.1251 & 2.4487 & 3.4265 & 48.7676 & 29.4852 \\
Skewness & -0.4673 & -0.0059 & 0.7015 & 5.7763 & -3.8809 \\
Count & 120 & 120 & 120 & 120 & 120 \\
\hline
\end{tabular}

Source: Authors. 
Table 4 represents the correlation matrix of explanatory variables. In Table 4, correlation coefficients between $R_{f}$, and $R_{m}-R_{f} ; R_{f}$ and $\mathrm{SMB}$, and $\mathrm{HML}$ and $\mathrm{UMD}$ are found significantly negative at $1 \%$ level of significance. In addition, correlation coefficients between $R_{m}-R_{f}$ and SMB; and $R_{m}-R_{f}$ and UMD are found negatively significant at 5\% level of significance. On the other hand, the correlation between $R_{f}$ and UMD is found negatively significant at $10 \%$ level of significance. However, small correlation among factors ensures that there is no outlier and autocorrelation problem in the data set used in this study.

Table 4. Correlation matrix of explanatory variables

\begin{tabular}{|c|c|c|c|c|c|}
\hline & $R_{f}$ & $R_{m}-R_{f}$ & SMB & HML & UMD \\
\hline \multirow[t]{2}{*}{$R_{f}$} & 1.0000 & & & & \\
\hline & $-0.2608^{*}$ & & & & \\
\hline \multirow[t]{2}{*}{$R_{m}-R_{f}$} & $(0.0040)$ & 1.0000 & & & \\
\hline & $-0.2725^{*}$ & $-0.1819^{* *}$ & & & \\
\hline \multirow[t]{2}{*}{ SMB } & $(0.0026)$ & $(0.0468)$ & 1.0000 & & \\
\hline & 0.0061 & -0.0300 & -0.1482 & & \\
\hline \multirow[t]{2}{*}{ HML } & $(0.9469)$ & $(0.7451)$ & $(0.1063)$ & 1.0000 & \\
\hline & $-0.1525^{* * *}$ & $0.2118^{* *}$ & 0.1231 & $-0.7109^{*}$ & \\
\hline UMD & $(0.0963)$ & $(0.0202)$ & (0.1803) & $(0.0000)$ & 1.0000 \\
\hline
\end{tabular}

Source: Authors. Figures within parenthesis indicate $p$ - values.

Asterisk $*, * *, * * *$ represent level of significance at $1 \%, 5 \%, 10 \%$, respectively.

\subsection{Regression Results for Size and Book-to-Market Portfolios}

Regression coefficients of each of the six portfolios of sub-section 3.2 are estimated by the equation (6) of sub-section 3.3 and presented in Table 5. Results inTable 5 show that there exist significant (at $1 \%$ level of significance) and positive linear relation between mean monthly excess return and market risk premium in DSE for all portfolios of sub-section 3.2.

Table 5. Regression results for size and book-to-market portfolios

\begin{tabular}{|c|c|c|c|c|c|c|c|c|c|}
\hline Portfolios & & $\beta_{\alpha}$ & $\beta_{R_{m}-R_{f}}$ & $\beta_{S M B}$ & $\beta_{H M L}$ & $\beta_{U M D}$ & $R^{2}$ & F-value & Sig. \\
\hline \multirow{3}{*}{$\mathrm{B} / \mathrm{H}$} & Coefficient & -0.9681 & 0.7513 & 0.3743 & 0.0362 & 0.4245 & \multirow{3}{*}{0.38} & \multirow{3}{*}{$19.3077^{*}$} & \multirow{3}{*}{0.0000} \\
\hline & $\mathrm{t}$-value & -1.0451 & $6.5712^{*}$ & $2.6550^{*}$ & 0.3090 & $2.7230^{*}$ & & & \\
\hline & P-value & 0.2982 & 0.0000 & 0.0091 & 0.7579 & 0.0075 & & & \\
\hline \multirow{3}{*}{$\mathrm{B} / \mathrm{M}$} & Coefficient & -1.3951 & 0.913 & 0.2731 & -0.2687 & 0.4698 & \multirow{3}{*}{0.63} & \multirow{3}{*}{$50.6632 *$} & \multirow{3}{*}{0.0000} \\
\hline & $\mathrm{t}$-value & $-1.789^{* * * *}$ & $9.4876^{*}$ & $2.3016^{* *}$ & $-2.7245^{*}$ & $3.5801^{*}$ & & & \\
\hline & P-value & 0.0762 & 0.0000 & 0.0232 & 0.0074 & 0.0005 & & & \\
\hline \multirow{3}{*}{$\mathrm{B} / \mathrm{L}$} & Coefficient & -0.9692 & 0.5922 & 0.3464 & -1.2657 & 0.6601 & \multirow{3}{*}{0.77} & \multirow{3}{*}{$102.7150^{*}$} & \multirow{3}{*}{0.0000} \\
\hline & $\mathrm{t}$-value & -0.9581 & $4.7436^{*}$ & $2.2502^{* *}$ & $-9.8936^{*}$ & $3.8775^{*}$ & & & \\
\hline & $\mathrm{P}$-value & 0.34 & 0.0000 & 0.0263 & 0.0000 & 0.0002 & & & \\
\hline \multirow{3}{*}{$\mathrm{S} / \mathrm{H}$} & Coefficient & -1.1345 & 0.6453 & 1.3255 & -0.202 & 0.5930 & \multirow{3}{*}{0.61} & \multirow{3}{*}{$46.9574^{*}$} & \multirow{3}{*}{0.0000} \\
\hline & $\mathrm{t}$-value & -1.1783 & $5.4305^{*}$ & $9.0467^{*}$ & $-1.659^{* * *}$ & $3.6597^{*}$ & & & \\
\hline & P-value & 0.2411 & 0.0000 & 0.0000 & 0.0999 & 0.0004 & & & \\
\hline \multirow{3}{*}{$\mathrm{S} / \mathrm{M}$} & Coefficient & -1.0644 & 0.8068 & 1.3148 & -0.3962 & 0.6040 & \multirow{3}{*}{0.69} & \multirow{3}{*}{$66.9072^{*}$} & \multirow{3}{*}{0.0000} \\
\hline & $\mathrm{t}$-value & -1.1493 & $7.0589^{*}$ & $9.3293^{*}$ & $-3.3824^{*}$ & $3.8752^{*}$ & & & \\
\hline & P-value & 0.2528 & 0.0000 & 0.0000 & 0.0010 & 0.0002 & & & \\
\hline \multirow{3}{*}{$\mathrm{S} / \mathrm{L}$} & Coefficient & -1.1334 & 0.8044 & 1.3534 & -0.9001 & 0.3574 & \multirow{3}{*}{0.78} & \multirow{3}{*}{$106.0697^{*}$} & \multirow{3}{*}{0.0000} \\
\hline & $\mathrm{t}$-value & -1.3058 & $7.5084^{*}$ & $10.2459^{*}$ & $-8.1990^{*}$ & $2.4466^{* *}$ & & & \\
\hline & P-value & 0.1942 & 0.0000 & 0.0000 & 0.0000 & 0.0159 & & & \\
\hline
\end{tabular}

Source: Authors. Asterisk *,**, *** represent level of significance at 1\%, 5\%,10\%, respectively.

That means, market beta has significant impact on excess return of portfolios in DSE. Thus, this finding rejects the evidence of no positive relationship between market risk premium and stock return of Mobarek and Mollah (2005) and Chowdhury and Sharmin (2013). Since this study finds a strong positive relationship between market 
risk premium and excess return with lower standard error for all six portfolios in Table 5, it also rejects the flat relationship between market risk premium and stock return of Fama and French (1992) in DSE. Table 5 also reveals that size premium is statistically significant for all six portfolios of sub-section 3.2. Of which small size portfolios (i.e. S/H, S/M, and S/L) are found significant at $1 \%$ level of significance, and big size portfolios $(\mathrm{B} / \mathrm{H}$, $\mathrm{B} / \mathrm{M}$, and $\mathrm{B} / \mathrm{L}$ ) are found significant at $5 \%$ level of significance in DSE. In addition, Table 5 reports that coefficients of size premium for small size portfolios are found larger than the same of big size portfolios in DSE. This implies that size premium (i.e. SMB) has greater impact in the excess return of small size portfolios in DSE. Regarding value premium, Table 5 finds that it is significantly and negatively related with the excess returns of all portfolios except the portfolio $\mathrm{B} / \mathrm{H}$. In addition, value premium are found significant at $1 \%$ level of significance for portfolio $\mathrm{B} / \mathrm{L}, \mathrm{S} / \mathrm{M}$, and $\mathrm{S} / \mathrm{L}$; and the same for portfolio $\mathrm{B} / \mathrm{M}$ is found significant at $5 \%$ level of significance in Table 5. Interestingly value premium for all low portfolios are found statistically significant in Table 5. The momentum factor (UMD) of Table 5 is found positively and significantly related with the excess returns of all portfolios except the portfolio $\mathrm{S} / \mathrm{L}$ at $1 \%$ level of significance. On the other hand, portfolio $\mathrm{S} / \mathrm{L}$ is found significant at 5\% level of significance. This implies strong presence of momentum effect in DSE, at least for the sample period of this study. The goodness of fit of the model is highly acceptable considering the magnitude of F-statistic. For all six portfolios, F-statistics is found significant at $1 \%$ level of significance, which implies that four-factor asset pricing model is valid in an emerging stock market like DSE. The R2 value is also satisfactory in case of all portfolios except portfolio $\mathrm{B} / \mathrm{H}$. On an average, more than $60 \%$ return variation is explained by the four-factors of equation (6) section 3.

\subsection{Regression Results for Size and Momentum Portfolios}

Table 6 represents the regression results of four portfolios of sub-section 3.2. Table 6 reveals that market beta is significant for all portfolios such as big-up (B/U), big-down (B/D), small-up (S/U), and small-down (S/D) at $1 \%$ level of significance.

Table 6. Regression results of size and momentum portfolios

\begin{tabular}{|c|c|c|c|c|c|c|c|c|c|}
\hline Portfolios & & $\beta_{\alpha}$ & $\beta_{R_{m}-R_{f}}$ & $\beta_{S M B}$ & $\beta_{H M L}$ & $\beta_{U M D}$ & $R^{2}$ & F-value & Sig. \\
\hline \multirow{3}{*}{$\mathrm{B} / \mathrm{U}$} & Coefficient & -1.3616 & 0.8377 & 0.2908 & -0.5727 & 0.9157 & \multirow{3}{*}{0.74} & \multirow{3}{*}{$86.2463^{*}$} & \multirow{3}{*}{0.0000} \\
\hline & $\mathrm{t}$-value & -1.5424 & $7.6889^{*}$ & $2.1648^{* * *}$ & $-5.1300^{*}$ & $6.1641^{*}$ & & & \\
\hline & P-value & 0.1257 & 0.0000 & 0.0325 & 0.0000 & 0.0000 & & & \\
\hline \multirow{3}{*}{$\mathrm{B} / \mathrm{D}$} & Coefficient & -0.9556 & 0.8425 & 0.3227 & -0.3956 & 0.0250 & \multirow{3}{*}{0.50} & \multirow{3}{*}{$30.1141^{*}$} & \multirow{3}{*}{0.0000} \\
\hline & $\mathrm{t}$-value & -1.1789 & $8.4213^{*}$ & $2.6160^{* *}$ & $-3.8584^{*}$ & 0.1835 & & & \\
\hline & P-value & 0.2409 & 0.0000 & 0.0101 & 0.0002 & 0.8547 & & & \\
\hline \multirow{3}{*}{$\mathrm{S} / \mathrm{U}$} & Coefficient & -1.0002 & 0.7759 & 1.3577 & -0.4232 & 1.0737 & \multirow{3}{*}{0.79} & \multirow{3}{*}{$114.1689^{*}$} & \multirow{3}{*}{0.0000} \\
\hline & $\mathrm{t}$-value & -1.1453 & $7.1986^{*}$ & $10.2155^{*}$ & $-3.8313^{*}$ & $7.3056^{*}$ & & & \\
\hline & P-value & 0.2545 & 0.0000 & 0.0000 & 0.0002 & 0.0000 & & & \\
\hline \multirow{3}{*}{ S/D } & Coefficient & -1.4062 & 0.7711 & 1.3258 & -0.6003 & -0.0356 & \multirow{3}{*}{0.60} & \multirow{3}{*}{$45.8958^{*}$} & \multirow{3}{*}{0.0000} \\
\hline & $\mathrm{t}$-value & -1.4748 & $6.5528^{*}$ & $9.1371^{*}$ & $-4.9785^{*}$ & -0.2216 & & & \\
\hline & P-value & 0.143 & 0.0000 & 0.0000 & 0.0000 & 0.8251 & & & \\
\hline
\end{tabular}

Source: Authors. Asterisks *, **, *** represent level of significance at $1 \%, 5 \%, 10 \%$, respectively.

Such finding implies that positive risk-return relationship exists in DSE. Table 6 also reports that size premium (SMB) is found significant for all small size portfolios such as small-up (S/U) and small-down (S/D) at $1 \%$ level of significance, whereas big-up (B/U) and big-down (B/D) portfolios are found significant at $5 \%$ level of significance in DSE. In addition, coefficients of size premium (SMB) with small portfolios are found higher than the same of big portfolios in DSE. On the other hand, value premium (HML) is found significantly and negatively related with the excess return of all portfolios in Table 6 at $1 \%$ level of significance. In addition, momentum factor in Table 6 is found statistically significant for all up portfolios at $1 \%$ level of significance. It is also observed that estimated coefficients are found positive and larger for the all up portfolios in Table 6 . Interestingly momentum factor fails to explain the return of down portfolios in DSE. There may be a factor like return reversal of Rosenberg et al. (1985) for the down portfolios. However, $R^{2}$ value in Table 6 declares that four-factor model of equation (6) fitted nicely with the data set used in this study. This value is found reasonably high for up portfolios (near about $77 \%$ on average) and low for down portfolios (near about $55 \%$ on average). Finally, $F$-statistic in Table 6 is found significant at $1 \%$ level of significance. Therefore, it could be claimed that four-factor CAPM is valid in DSE. 


\subsection{Robustness of Regression Results}

This section considers within sample prediction accuracy of parameters estimated for all portfolios in Table 5 and Table 6 in order to check robustness of the regression results. For this purpose, firstly expected return for each of the ten portfolios in Table 7 is calculated by the four-factor model in equation (6) for each year of the sample period.

Table 7. Average expected return of portfolios over the sample period

\begin{tabular}{lcccccccccc}
\hline Portfolios & 2005 & 2006 & 2007 & 2008 & 2009 & 2010 & 2011 & 2012 & 2013 & 2014 \\
\hline B/H & -0.0522 & 0.3995 & 4.8225 & -0.4744 & 4.7075 & 8.0869 & -4.9702 & -1.1046 & 0.3664 & 1.4451 \\
B/M & -0.6919 & 0.1191 & 6.3225 & -1.1439 & 4.1636 & 7.0888 & -8.2538 & -1.5672 & 1.0231 & 1.6117 \\
B/L & -1.0314 & 0.4830 & 6.6145 & -2.2233 & -0.3942 & 2.1576 & -16.4577 & -1.2386 & 3.7319 & 1.3182 \\
S/H & 0.9918 & 1.9005 & 3.7929 & -0.2595 & 5.3005 & 12.9698 & -8.0067 & -1.2916 & 0.9384 & 1.4623 \\
S/M & 0.5502 & 1.7659 & 4.9167 & -0.6873 & 5.2789 & 12.8953 & -10.1879 & -1.7334 & 1.2885 & 1.6355 \\
S/L & 0.0326 & 1.9670 & 4.9683 & -0.9163 & 3.3251 & 9.9477 & -12.3877 & -1.8222 & 2.2606 & 1.6429 \\
B/U & -0.7152 & 0.0448 & 7.5219 & -2.0492 & 3.2215 & 7.1144 & -13.6668 & -1.6517 & 2.1527 & 1.5582 \\
B/D & -0.7897 & 0.4449 & 4.9582 & -0.5592 & 3.0946 & 4.8135 & -5.7805 & -1.3072 & 0.9954 & 1.5324 \\
S/U & 0.7635 & 1.6646 & 5.9497 & -1.3238 & 5.5704 & 14.6299 & -13.7391 & -1.8454 & 1.7511 & 1.6249 \\
S/D & 0.2215 & 2.0906 & 3.3917 & 0.0176 & 3.8301 & 9.4881 & -7.0150 & -1.5012 & 1.2650 & 1.5835 \\
Average & -0.0721 & 1.0880 & 5.3259 & -0.9619 & 3.8098 & 8.9192 & -10.0465 & -1.5063 & 1.5773 & 1.5415 \\
\hline
\end{tabular}

Source: Authors.

As for example, expected return of portfolio $\mathrm{B} / \mathrm{H}$ is calculated by the four-factor model in equation (6) for the year 2005 to 2014. Same procedure is applied to other portfolios in Table 7. Secondly, annual expected return for each sample year is calculated by taking average of expected return of all portfolios of that particular year. That is, average expected return for 2005 is calculated with the expected return of ten portfolios in 2005 . This procedure is repeated for other sample years in Table 7.

Table 8. Average actual return of the portfolios over the sample period

\begin{tabular}{lcccccccccc}
\hline Portfolios & 2005 & 2006 & 2007 & 2008 & 2009 & 2010 & 2011 & 2012 & 2013 & 2014 \\
\hline B/H & -1.1319 & 0.2711 & 3.9454 & 3.2470 & 8.2951 & 2.6460 & -11.3782 & -3.2993 & 0.4045 & 0.5458 \\
B/M & -2.7909 & -0.9555 & 4.4747 & 3.5110 & 3.7861 & 2.3039 & -12.9849 & -3.6801 & 1.4461 & -0.3891 \\
B/L & -2.2601 & -0.8588 & 4.7438 & 1.1125 & 3.1733 & -2.0458 & -22.6775 & -2.9812 & 5.2986 & -0.2365 \\
S/H & -0.2777 & 1.0162 & 1.9888 & 3.3318 & 8.2110 & 7.2804 & -14.1678 & -3.1164 & 1.9819 & 0.2051 \\
S/M & -1.4672 & -0.2236 & 2.9355 & 3.4565 & 6.2156 & 11.0825 & -15.0365 & -3.6819 & 2.7577 & -0.9603 \\
S/L & -1.0880 & 2.2961 & 4.1578 & 3.0607 & 6.2557 & 3.0208 & -18.7369 & -4.0992 & 1.7755 & 1.0410 \\
B/U & -3.1222 & -0.7852 & 6.0103 & 1.8163 & 4.1713 & 1.0334 & -19.5867 & -3.0794 & 3.5730 & -0.1161 \\
B/D & -2.9787 & -0.6480 & 4.2871 & 3.8152 & 3.2956 & 1.5146 & -11.4899 & -2.8668 & 2.2798 & 0.6371 \\
S/U & -0.2259 & 0.1319 & 3.3985 & 2.4971 & 7.1618 & 11.5189 & -19.1589 & -4.0116 & 2.6349 & 1.0968 \\
S/D & -0.9858 & 0.8208 & 0.0000 & 3.3295 & 6.1703 & 3.5950 & -12.6453 & -3.5355 & 2.2847 & 0.2765 \\
Average & -1.6328 & 0.1065 & 3.5942 & 2.9178 & 5.6736 & 4.1950 & -15.7863 & -3.4351 & 2.4437 & 0.2100 \\
\hline
\end{tabular}

Source: Authors.

Thirdly, annual actual return for each sample year is calculated by taking average of actual returns of each of the ten portfolios in Table 8 of that particular year. Fourthly, differences between average expected and actual return of each sample year are calculated in Table 9 and tests if these differences are statistically significant. The $p$-value in Table 9 evident that differences between average yearly expected and actual return for six sample years such as 2005, 2006, 2007, 2012, and 2014 are found insignificant; whereas the same for 2008, 2009, 2010, and 2011 are found significant at 1\% level of significance and for year 2013 at 5\% level of significance. The possible reason of such findings might be the stock market crash in DSE during that sample years. Therefore, it is evident that statistically accurate prediction of actual returns could be possible by four-factor CAPM in DSE. This is also evident in Figure 1 of this study. In Figure 1, the solid line represents average yearly actual return of portfolios of Table 9 and dotted line represents average yearly expected return of the same over the sample years. It is evident from Figure 1 that both solid and dotted lines moves following almost same shape and some segments of the both match exactly with each other. But the dotted line maintains a distance from the solid one in 2008 to 2010. 
Table 9. Differences between expected and actual return of portfolios

\begin{tabular}{cccccc}
\hline Year & Actual & Expected & Differences & $\mathrm{t}$ - value & $p$-value \\
\hline 2005 & -1.63283 & -0.07206 & -1.5607 & 0.4670 & 0.3257 \\
2006 & 0.106498 & 1.088 & -0.9815 & 0.1741 & 0.4328 \\
2007 & 3.594173 & 5.325896 & -1.7317 & 0.6562 & 0.2640 \\
2008 & 2.917763 & -0.96193 & 3.8796 & 5.5548 & 0.0001 \\
2009 & 5.673578 & 3.809796 & 1.8637 & 3.3234 & 0.0044 \\
2010 & 4.19497 & 8.919189 & -4.7242 & 3.9685 & 0.0016 \\
2011 & -15.7863 & -10.0465 & -5.7397 & 5.0925 & 0.0003 \\
2012 & -3.43513 & -1.50631 & -1.9288 & 0.8744 & 0.2023 \\
2013 & 2.443666 & 1.577313 & 0.8663 & 2.2194 & 0.0268 \\
2014 & 0.210031 & 1.541468 & -1.3314 & 0.2131 & 0.4179 \\
\hline
\end{tabular}

Source: Authors.

During that time period a crash has occurred in DSE. Which means that four-factor model in equation (6) of this study could predict actual returns accurately in normal time period in DSE. Therefore, it can be said that estimated parameters of four-factor model of equation (6) are robust.

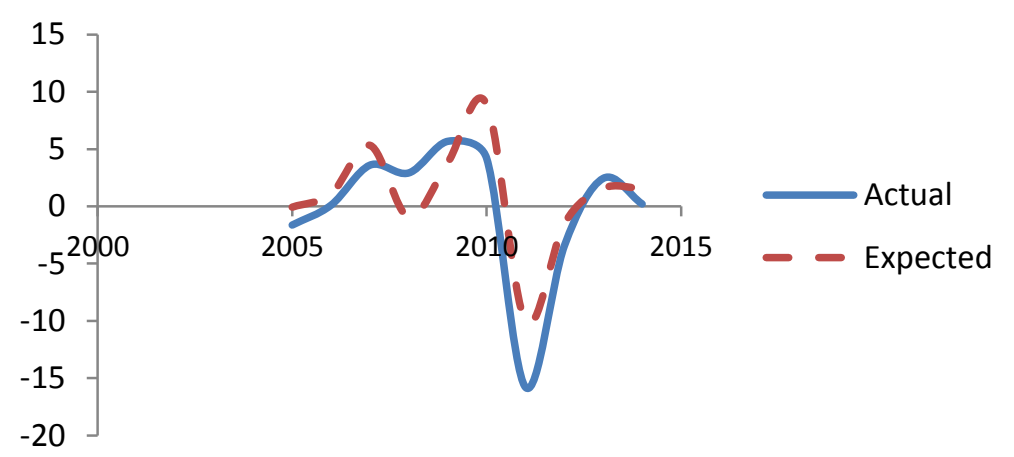

Figure 1. Comparison between expected and actual returns of portfolios for the sample period

\section{Conclusion}

The main objective of this study is to find factors of stock returns by Carhart model in Dhaka Stock Exchange of Bangladesh. This objective has been pursued by testing significant relationship between excess return of ten portfolios constructed from 109 out of 333 stocks listed with DSE for a sample period of 2005-2014 and return factors such as market risk premium, size, book-to-market ratio, and momentum. Sample stocks include non-financial and actively traded local and foreign companies in DSE. Multiple regression technique is applied to test if there is any significant relationship between excess return and its factors in DSE. This study empirically finds the presence of size and value effect, having a policy implication for stock investors that small firms outperform big firms in terms of mean monthly returns in DSE. Regarding value premium in DSE, it is found that value premium is high with big portfolios and reject the finding of Fama and French (1993) that higher value premium exists with small portfolios in the stock market of developed countries. Therefore, this finding might be considered as one of the exceptional features of DSE; and value investors in this market may be benefited from investing on big size portfolios. Momentum factor produces positive return for small portfolios, while it produces negative return for big portfolios in DSE. Therefore, it is evident that small portfolios dominate over big portfolios in DSE in terms of size and momentum effects. Regression results of both types of portfolios, size and book-to-market and size and momentum, of this study find that market risk premium is a significant factor of stock returns in DSE, and has positive relationship with portfolio returns. Therefore, stocks with high beta will produce higher return than that of with low beta in DSE. This finding supports the classical relationship between risk and return in DSE. Therefore, it rejects the findings of no or negative relationship between beta and stock returns of earlier studies that have been conducted on DSE. Size premium as another return factor is found significant in this study. It is interesting that coefficients of size premium for small size portfolios are found larger than the same of big size portfolios in DSE, and implies that size premium of small capitalized firms outperform big capitalized firms in DSE.The value premium, on the other hand, is found negatively related with 
the returns of all portfolios except one in DSE; and violates the theoretical argument of positive relationship between value premium and stock returns of four-factor asset pricing model. Therefore, it might be considered as another distinct feature of four-factor model in emerging stock market like DSE. However, for size and book-to-market portfolios this negativity decreases from low to high portfolios and implies that firms with high book-to-market value produce higher return than firms with low book-to-market value in DSE. Alternatively, the small size and high value portfolios produce higher return in DSE. In addition, momentum factor in DSE is found positively and significantly related with the returns of small size and all up portfolios constructed based on size and book-to-market and size and momentum, respectively. For both the cases of size and book-to-market and size and momentum portfolios the four-factors of this study explain, on an average, more than $60 \%$ return variations. It is also evident in this study that four-factor model can predict portfolio returns accurately when there is no abnormality such as market crash occurs. Finally, $F$-test and $R^{2}$ value reveal that four-factor model nicely fitted with the data set used in this study. In a nutshell, four-factor asset pricing model can be applied to explain return variations; calculate expected return of portfolios and the price as well in emerging stock market in general and DSE in particular. However, this study suffers from some drawbacks such as small sample period and absence of out of sample return predictions for robustness test. Future researches could be initiated to investigate why the alpha value of equation (6) is not zero as it is supposed to be and what might be the reasons of negative momentum return in DSE with big portfolios etc.

\section{Acknowledgments}

The authors of this paper would like to thank anonymous reviews of the first international conference on "Finance for Sustainable Growth and Development" organized by Department of Finance, University of Chittagong, Bangladesh for their valuable comments.

\section{References}

Ammann, M., \& Steiner, M. (2008).Risk factors for the Swiss stock market.Swiss Journal of Economics and Statistics, 144(1), 1-35. http://dx.doi.org/10.2139/ssrn.1088379

Artmann, S., Finter, P., \& Kempf, A. (2012). Determinants of expected stock returns: large sample evidence from the German market. Journal of Business Finance \& Accounting, 39(5-6), 758-784. https://doi.org/10.1111/j.1468-5957.2012.02286.x

Banz, R. W. (1981). The relationship between return and market value of common stocks. Journal of Financial Economics, 9(1), 3-18. https://doi.org/10.1007/BF02920488

Basu, S. (1977). Investment performance of common stocks in relation to their price-earnings ratios: A test of the efficient market hypothesis. The Journal of Finance, 32(3), 663-682. https://doi.org/10.1111/j.1540-6261.1977.tb01979.x

Black, F. (1992). Beta and return. Journal of Portfolio Management, 1. https://doi.org/10.2469/faj.v51.n1.1873

Bretschger, L., \& Lechthaler, F. (2012). Common Risk Factors and Macroeconomy: New Evidence from the Japanese Stock Market. Economic working paper series 12/160. Centre for Economic Research ETH- Zurich. https://doi.org/10.2139/ssrn.2044464

Carhart, M. M. (1997). On persistence in mutual fund performance. The Journal of Finance, 52(1), 57-82. https://doi.org/10.1111/j.1540-6261.1997.tb03808.x

Chowdhury, S. S. H., \& Sharmin, R. (2013). Relevant Factors to Explain Cross-Section of Expected Returns of the Firms Listed in the Dhaka Stock Exchange. International Business Research, 6(3), 165. https://doi.org/10.5539/ibr.v6n3p165

Czapkiewicz, A., \& Wójtowicz, T. (2014).The four-factor asset pricing model on the Polish stock $\begin{array}{llll}\text { market.Economic } & \text { research-Ekonomska istraživanja, } & 27(1), & \text { 771-783. }\end{array}$ https://doi.org/10.1080/1331677X.2014.975518

Fama, E. F., \& French, K. R. (1992). The cross - section of expected stock returns. The Journal of Finance, 47(2), 427-465. https://doi.org/10.1111/j.1540-6261.1992.tb04398.x

Fama, E. F., \& French, K. R. (1993). Common risk factors in the returns on stocks and bonds. Journal of Financial Economics, 33(1), 3-56. https://doi.org/10.1111/1540-6229.00717

Fama, E. F., \& French, K. R. (1996). Multifactor explanations of asset pricing anomalies. The Journal of Finance, 51(1), 55-84. https://doi.org/10.1111/j.1540-6261.1996.tb05202.x

Fama, E. F., \& French, K. R. (2012). Size, value, and momentum in international stock returns. Journal of 
Financial Economics, 105(3), 457-472. https://doi.org/10.2469/dig.v42.n4.49

Gregory, A., Tharyan, R., \& Christidis, A. (2013). Constructing and testing alternative versions of the Fama-French and Carhart models in the UK. Journal of Business Finance \& Accounting, 40(1-2), $172-214$. https://doi.org/10.1111/jbfa.12006

Griffin, J. M., \& Lemmon, M. L. (2002). Book-to-market equity, distress risk, and stock returns. The Journal of Finance, 57(5), 2317-2336. https://doi.org/10.1111/1540-6261.00497

Hasan, M. B., Alam, M. N., Amin, M. R., \& Rahaman, M. A. (2015). The size and value effect to explain cross-section of expected stock returns in Dhaka Stock Exchange. International Journal of Economics and Finance, 7(1), 14. https://doi.org/10.5539/ijef.v7n1p14

Hossan, M. A., \& Park,S. B. (2010). A Study on the Performances of Return Based Trading Strategies: The Case of Dhaka Stock Exchange (DSE) of Bangladesh. Journal of Industrial Economics and Business, 23(3), 1571-1592.

Hossan, M. A., \&Park, S. B. (2010). Sources of momentum profits in emerging stock markets: The case of Dhaka stock exchange. Indian Journal of Finance, 7(11), 16-27.

Jegadeesh, N., \& Titman, S. (1993). Returns to buying winners and selling losers: Implications for stock market efficiency. The Journal of Finance, 48(1), 65-91. https://doi.org/10.1111/j.1540-6261.1993.tb04702.x

Jensen, M. C. (1968). The performance of mutual funds in the period 1945-1964. The Journal of Finance, 23(2), 389-416. https://doi.org/10.2139/ssrn.244153

LaPorta, R., Lakonishok, J., Shleifer, A., \& Vishny, R. (1997). Good news for value stocks: Further evidence on market efficiency. Journal of Finance, 859-874. https://doi.org/10.1111/j.1540-6261.1997.tb04825.x

Lintner, J. (1965). Security prices, risk, and maximal gains from diversification. The Journal of Finance, 20(4), 587-615. https://doi.org/10.1111/j.1540-6261.1965.tb02930.x

Lozano, M. (2006). Estimating and Evaluating the Fama-French \& Carhart Models. Paper presented at the IV Workshop in Quantitative Finance.

Mobarek, A., \& Mollah, A. S. (2005). The General determinants of share returns: an empirical investigation on the Dhaka Stock Exchange. Review of Pacific Basin Financial Markets and Policies, 8(04), 593-612. https://doi.org/10.1142/S0219091505000518

Mossin, J. (1966). Equilibrium in a capital asset market. Econometrica: Journal of the Econometric Society, 768-783. https://doi.org/10.2307/1910098.

Novak, J., \& Petr, D. (2011). CAPM Beta, Size, Book-to-Market, and Momentum in Realized Stock Returns. Finance a Uver: Czech Journal of Economics \& Finance, 61(1). https://doi.org/10.1080/17520843.2016.1148754

Nwani, C. (2015). An Empirical Investigation of Fama-French-Carhart Multifactor Model: UK Evidence. Journal of Economics and Finance, 6(1), 95-103. https://doi.org/10.9790/5933-061295103.

Rahman, M., Baten, M. A., \& Alam, A. (2006). An empirical testing of capital asset pricing model in Bangladesh. Journal of Applied Sciences, 6(3), 662-667. https://doi.org/10.3923/jas.2006.662.667

Rosenberg, B., Reid, K., \& Lanstein, R. (1985). Persuasive evidence of market inefficiency. Journal of Portfolio Management, 11, 9-17. https://doi.org/10.3905/jpm.1985.409007.

Sharpe, W. F. (1964). Capital asset prices: A theory of market equilibrium under conditions of risk. The Journal of Finance, 19(3), 425-442. https://doi.org/10.1111/j.1540-6261.1964.tb02865.x

Stattman, D. (1980). Book values and stock returns. The Chicago MBA: A Journal of Selected Papers, 4(1), 25-45.

Tjandrasa, B. B. (2015). The application of three-factor pricing model in LQ45 index. International Journal of Education and Research, 3(2), 483-496.

\section{Copyrights}

Copyright for this article is retained by the author(s), with first publication rights granted to the journal.

This is an open-access article distributed under the terms and conditions of the Creative Commons Attribution license (http://creativecommons.org/licenses/by/4.0/). 